\title{
Heterologous expression of nattokinase from B. subtilis natto using Pichia pastoris GS115 and assessment of its thrombolytic activity
}

Yan Guangbo', Shu Min ${ }^{1}$, Shen Wei ${ }^{1}$, Ma Lixin ${ }^{1}$, Zhai Chao ${ }^{1 *+}$, Wang Yaping ${ }^{1 *+}$ and Huang Zunxi ${ }^{2}$

\begin{abstract}
Background: Nattokinase is a fibrinolytic enzyme that has huge market value as a nutritional supplement for health promotion. In order to increase nattokinase yields, fermentation conditions, strains, cultivation media, and feeding strategies have been optimized. Nattokinase has been expressed using several heterologous expression systems. Pichia pastoris heterologous expression system was the alternative.

Results: This report aimed to express high levels of nattokinase from B. subtilis natto (NK-Bs) using a Pichia pastoris heterologous expression system and assess its fibrinolytic activity in vivo. Multicopy expression strains bearing 1-7 copies of the aprN gene were constructed. The expression level of the target protein reached a maximum at five copies of the target gene. However, multicopy expression strains were not stable in shake-flask or high-density fermentation, causing significant differences in the yield of the target protein among batches. Therefore, P. pastoris bearing a single copy of apr $\mathrm{N}$ was used in shake-flask and high-density fermentation. Target protein yield was 320 $\mathrm{mg} / \mathrm{L}$ in shake-flask fermentation and approximately $9.5 \mathrm{~g} / \mathrm{L}$ in high-density fermentation. The recombinant nattokinase showed high thermo- and pH-stability. The present study also demonstrated that recombinant NK-Bs had obvious thrombolytic activity.
\end{abstract}

Conclusions: This study suggests that the P. pastoris expression system is an ideal platform for the large-scale, lowcost preparation of nattokinase.

Keywords: Nattokinase; High-density fermentation; Multi-copy strains; Pichia pastoris

\footnotetext{
*Correspondence: chaozhai@hubu.edu.cn; 545080994@qq.com

${ }^{\dagger}$ Zhai Chao and Wang Yaping contributed equally to this work.

'State Key Laboratory of Biocatalysis and Enzyme, Engineering Hubei

Collaborative Innovation Center for Green Transformation of Bio-Resources,

Hubei Key Laboratory of Industrial Biotechnology, Biology Faculty of Hubei

University, Hubei University, Wuhan, Hubei Province 430062, People's

Republic of China

Full list of author information is available at the end of the article
}

(c) The Author(s). 2021 Open Access This article is licensed under a Creative Commons Attribution 4.0 International License, which permits use, sharing, adaptation, distribution and reproduction in any medium or format, as long as you give appropriate credit to the original author(s) and the source, provide a link to the Creative Commons licence, and indicate if changes were made. The images or other third party material in this article are included in the article's Creative Commons licence, unless indicated otherwise in a credit line to the material. If material is not included in the article's Creative Commons licence and your intended use is not permitted by statutory regulation or exceeds the permitted use, you will need to obtain permission directly from the copyright holder. To view a copy of this licence, visit http://creativecommons.org/licenses/by/4.0/ The Creative Commons Public Domain Dedication waiver (http://creativecommons.org/publicdomain/zero/1.0/) applies to the data made available in this article, unless otherwise stated in a credit line to the data. 


\section{Background}

Nattokinase (E.C 3.4.21.62) was first found in natto, a traditional Japanese fermented soybean food product [1]. Full length nattokinase includes 381 amino acids and is encoded by the apr $\mathrm{N}$ gene of B. subtilis natto [2]. After removal of the 29-amino acid signal peptide and 77amino acid propeptide from the precursor, the mature nattokinase consists of 275 amino acids and is $27.7 \mathrm{kDa}$ with an isoelectric point (pI) of pH 8.6 [2]. Nattokinase is a serine protease, and its activity is strongly inhibited by phenylmethylsulfonyl fluoride (PMSF). Because the enzyme is a cysteine-free proteinase, no disulfide bonds are observed on its structure [2]. A three-dimensional structural model of nattokinase from $B$. subtilis natto (NK-Bs) was constructed using homology modeling in 2005, and the crystal structure of the enzyme was published later (PDB: 4DWW, 3vyv) [3-5]. The catalytic center of nattokinase consists of Ser-His-Asp (D32, H64, S221), and Ser221 is the key residue for substrate recognition.

Nattokinase has been extensively studied because of its unique features as a fibrinolytic enzyme. Although nattokinase shows high similarity to many subtilisins in the serine protease family, it is the only member with thrombolytic activity. Nattokinase can directly cleave cross-linked fibrin in vitro and in vivo [6-8]. Moreover, it contributes to fibrin degradation by inactivating the fibrinolysis inhibitor PAI-1 [9] and catalyzing the conversion of pro-urokinase to urokinase. Furthermore, it stimulates cells to release the tissue plasminogen activator $\mathrm{t}-\mathrm{PA}$ and decreases plasma levels of fibrinogens. More importantly, unlike common fibrinolytic proteases such as t-PA and streptokinase, nattokinase has a long half-life in blood vessels and causes few side effects, such as bleeding or gastric ulcers. These characteristics make nattokinase a promising drug for the prevention and treatment of cardiovascular diseases. Currently, nattokinase products are used worldwide in the form of tablets or capsules as nutritional supplement for health promotion, including blooding thinning, blood clot prevention, and improving blood circulation [10-12].

Nattokinases are ideal for use in the clinic owing to the low costs associated with their industrial production. Nattokinase is obtained mainly through microbial fermentation, and nattokinase-producing strains have been isolated from natto, douche, and doen-jang. In order to increase nattokinase yields, fermentation conditions, strains, cultivation media, and feeding strategies have been optimized [13-18]. With the development of gene engineering, nattokinase has also been expressed using several heterologous expression systems, such as the multiple protease-deficient host strains $B$. subtilis WB800, Escherichia coli, Lactococcus lactis, Bacillus licheniformis, and Spodoptera frugiperda [19-24]. Our previous study indicated that the Pichia pastoris expression system is an ideal system for recombinant expression of protease, which is toxic to cells and causes cell lysis when large numbers of active enzyme molecules accumulate in cells. The tightly regulated $A O X 1$ promoter prevents leaky expression while secretory expression of the target protease alleviates the stress proteases cause to cells. Therefore, this system was chosen to obtain high-level expression of nattokinase. The results of the present study indicate that nattokinase from $B$. subtilis natto is able to be expressed at high titers using the $P$. pastoris system, and the recombinant nattokinase exhibits obvious thrombolytic activity along with strong $\mathrm{pH}-$ and thermo-stability.

\section{Results}

Multicopy expression of NK-Bs using P. pastoris GS115 The recombinant plasmid was named pHBM905BDMNK-Bs, transformed into P. pastoris GS115, and selected on MD plates without histidine. Twenty-two positive colonies were tested on BMMY media supplemented with $1 \%(\mathrm{w} / \mathrm{v})$ of casein. After induction with methanol for $48 \mathrm{~h}$, opaque halos appeared around seven colonies (Fig. 1), indicating that nattokinase from B. subtilis natto was successfully expressed by these colonies. These recombinants were named NK-Bs-1.

To improve target protein yield, multicopy expression vectors bearing two to seven copies of the NK-Bs expression cassette were constructed. The vectors were linearized and transformed into P. pastoris GS115. Positive transformants were named NK-Bs-2 to NK-Bs-7. NK-Bs-1 to NK-Bs-7 strains were inoculated onto

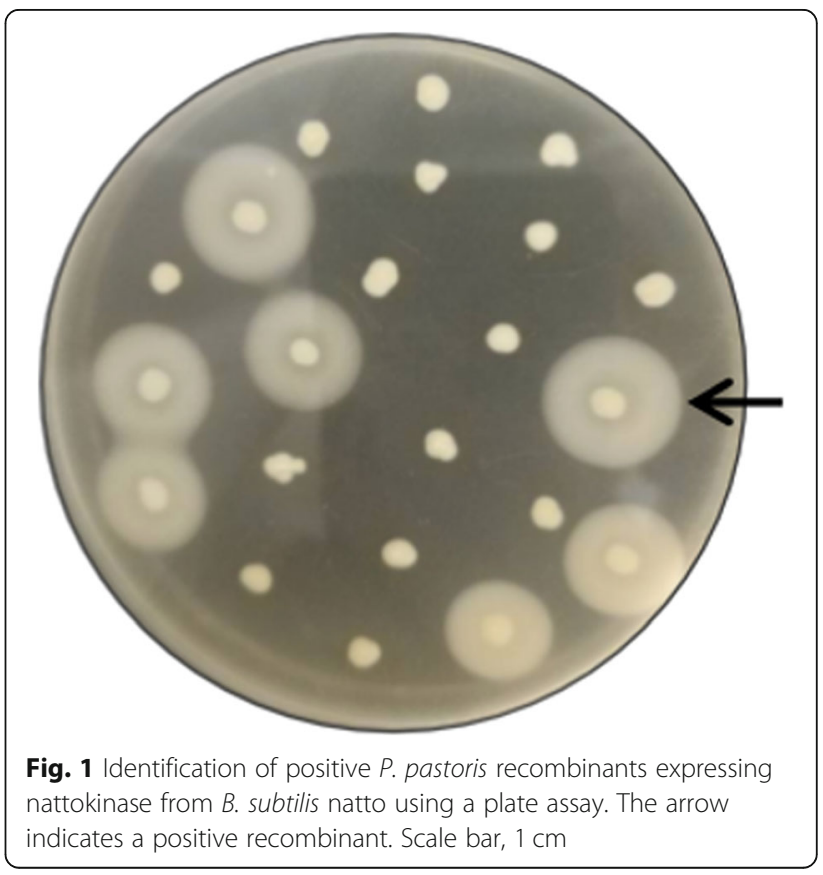




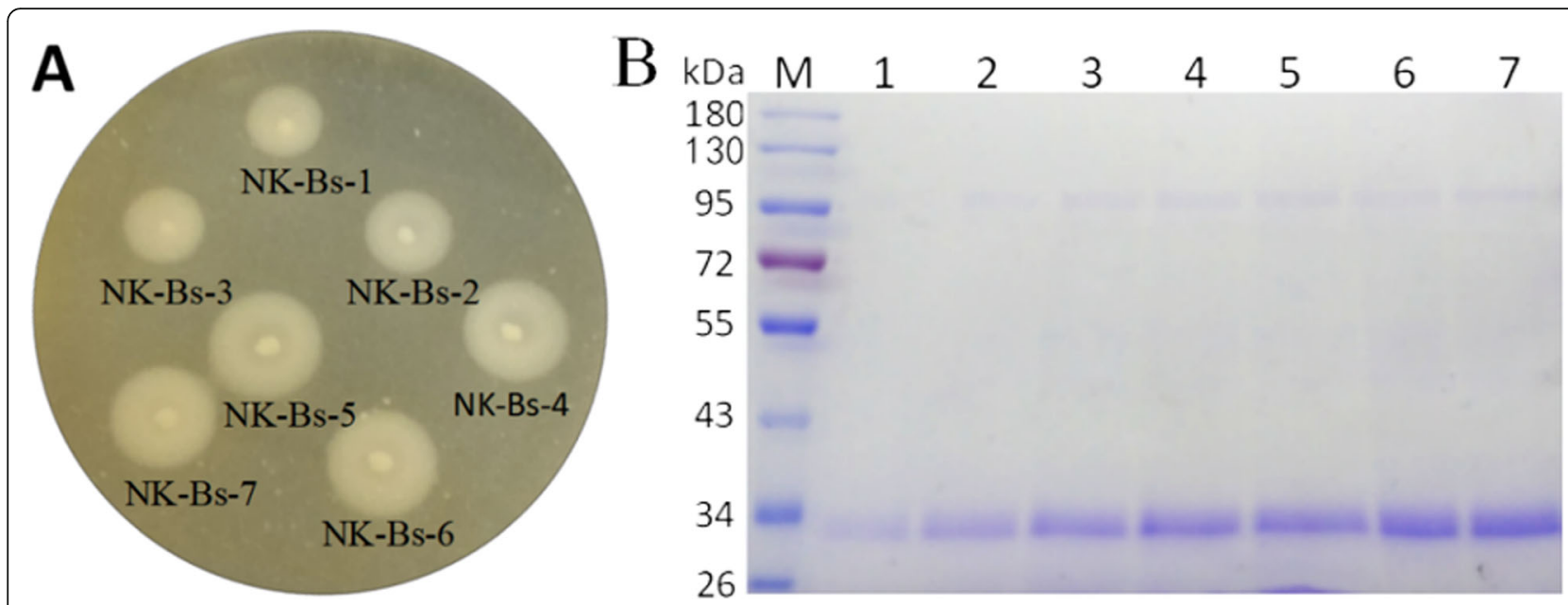

Fig. 2 Correlation between recombinant protein titer and gene copy number. A The relationship between NK-Bs expression levels and aprN gene copy number were assessed using a plate assay. The copy number of the target gene in each strain is indicated below each colony. The circle around each colony represents the average halo size of responding multicopy expression strains. Scale bar, $1 \mathrm{~cm}$. B SDS-PAGE analysis of NK-Bs secreted into the culture supernatant. M: protein molecular weight marker (the molecular weight of each band is indicated on the left); lanes 1-7: supernatants from shake-flask fermentation of NK-Bs 1-7 strains, respectively, collected after an 84-h induction with methanol. A total of $20 \mu \mathrm{L}$ of each sample was loaded

BMMY plates supplemented with casein. After two days, a clear, opaque halo formed around each colony. The diameter of the halos around the colonies increased significantly with increasing target gene copy number, suggesting a correlation between recombinant protein titer and gene copy number (Fig. S1). The size of the halo, indicating the effect of the gene copy number, reached a maximum at five copies (Fig. 2A, Table S2). Expression levels of the target protein in the multicopy expression strains were also analyzed using shake-flask fermentation. SDS-PAGE revealed a main band of approximately $34 \mathrm{kDa}$ after $84 \mathrm{~h}$ of induction, and the bands became more obvious as the number of gene copies increased
(Fig. 2B). These results indicate that higher gene copy numbers improved nattokinase yield.

\section{Shake-flask and high-density fermentation of NK-Bs}

Further study indicated that the multicopy expression strains were not stable during shake-flask or highdensity fermentation, causing remarkable differences in the titer of the target protein among batches. Therefore, to ensure the reliability of the results, strain NK-Bs-1 was used for all following experiments. With shake-flask fermentation, the $\mathrm{OD}_{600}$ of the cell culture was approximately 18 at the beginning of the induction and reached a maximum of approximately 24 after $120 \mathrm{~h}$ (Fig. 3A).
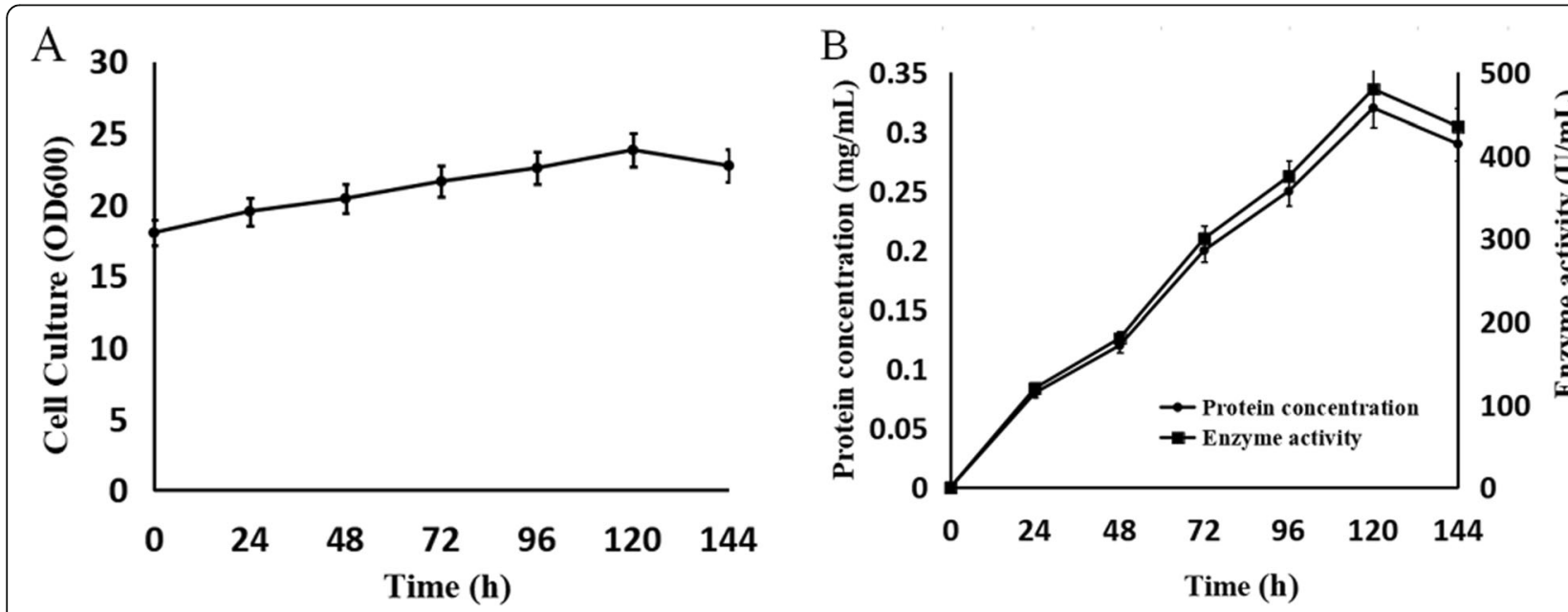

Fig. 3 Quantitative analysis of the expression of NK-Bs produced by shake-flask fermentation. A Time course of cell density during the induction phase. B Time course of the titer of the target protein and serine protease activity 


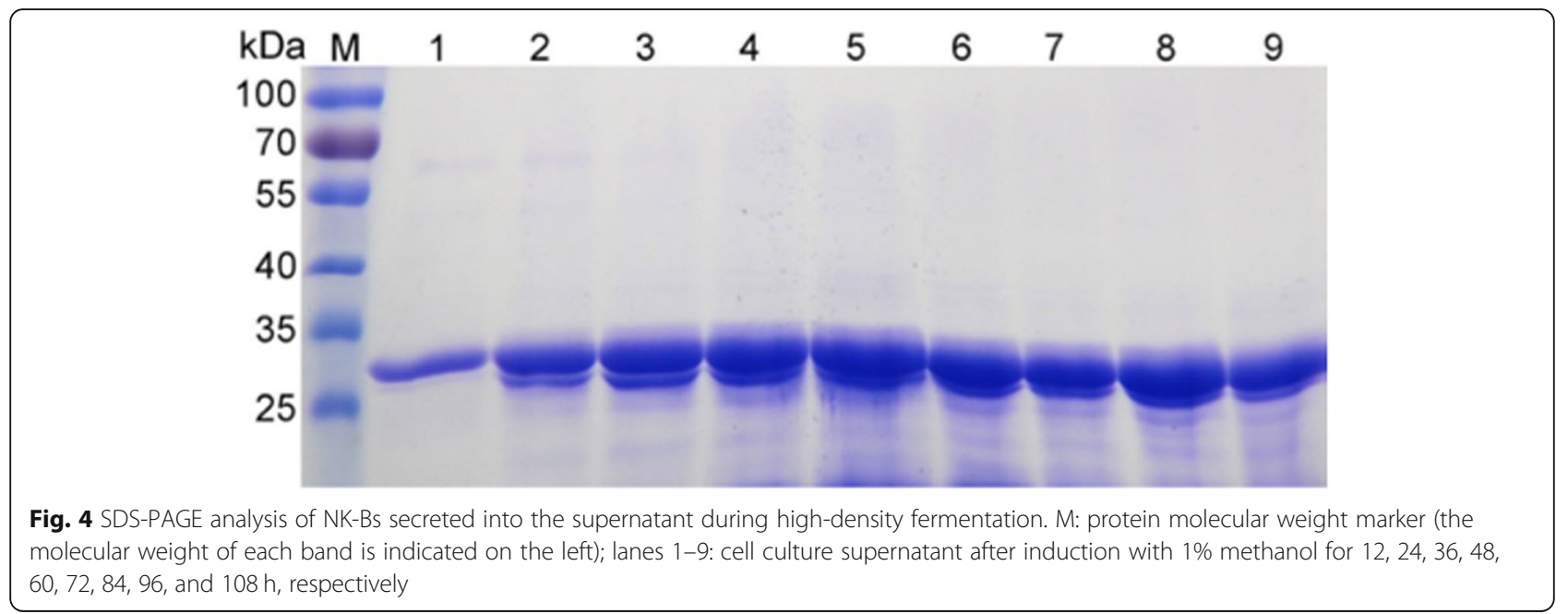

The protein concentration and enzyme activity of the recombinant protein were associated with cell growth and reached $0.32 \mathrm{~g} / \mathrm{L}$ and $480 \mathrm{U} / \mathrm{mL}$, respectively, after $120 \mathrm{~h}$ (Fig. 3B). In high-density fermentation, the yield of the target protein reached a maximum of approximately 9.5 $\mathrm{g} / \mathrm{L}$ and $15,421 \mathrm{U} / \mathrm{mL}$ after $96 \mathrm{~h}$ (Fig. 4).

\section{The characteristics of NK-Bs}

To study the characteristics of NK-Bs, the target protein was purified and concentrated (Fig. 5A). The recombinant NK-Bs was slightly larger than predicted. After Endo $\mathrm{H}$ treatment, the size of NK-Bs decreased to approximately $27 \mathrm{kDa}$, which was consistent with the predicted size of nattokinase (Fig. 5B). NK-Bs had high activity within a broad temperature and $\mathrm{pH}$ range. The optimal $\mathrm{pH}$ of the enzyme was $\mathrm{pH} 9.0$, and approximately $80 \%$ of its activity was retained at pH 8.0-10.0 (Fig. 6B). The optimal temperature of NK-Bs was $65^{\circ} \mathrm{C}$, and over $80 \%$ of its activity was retained at $75^{\circ} \mathrm{C}$ (Fig. 6A). NK-Bs exhibited outstanding stability at a wide range of $\mathrm{pH}$ values and retained almost full activity after incubation at $\mathrm{pH}$ 3.0-13.0 for $1 \mathrm{~h}$ (Fig. 7A). NK-Bs also had relatively high thermostability (Fig. 7B). NK-Bs retained over 50 and $40 \%$ of its enzymatic activity after incubation for $30 \mathrm{~min}$ at $60^{\circ} \mathrm{C}$ and $65^{\circ} \mathrm{C}$, respectively. However, its activity decreased dramatically above $65^{\circ} \mathrm{C}$, and its half-life was less than $10 \mathrm{~min}$ at $70^{\circ} \mathrm{C}$.

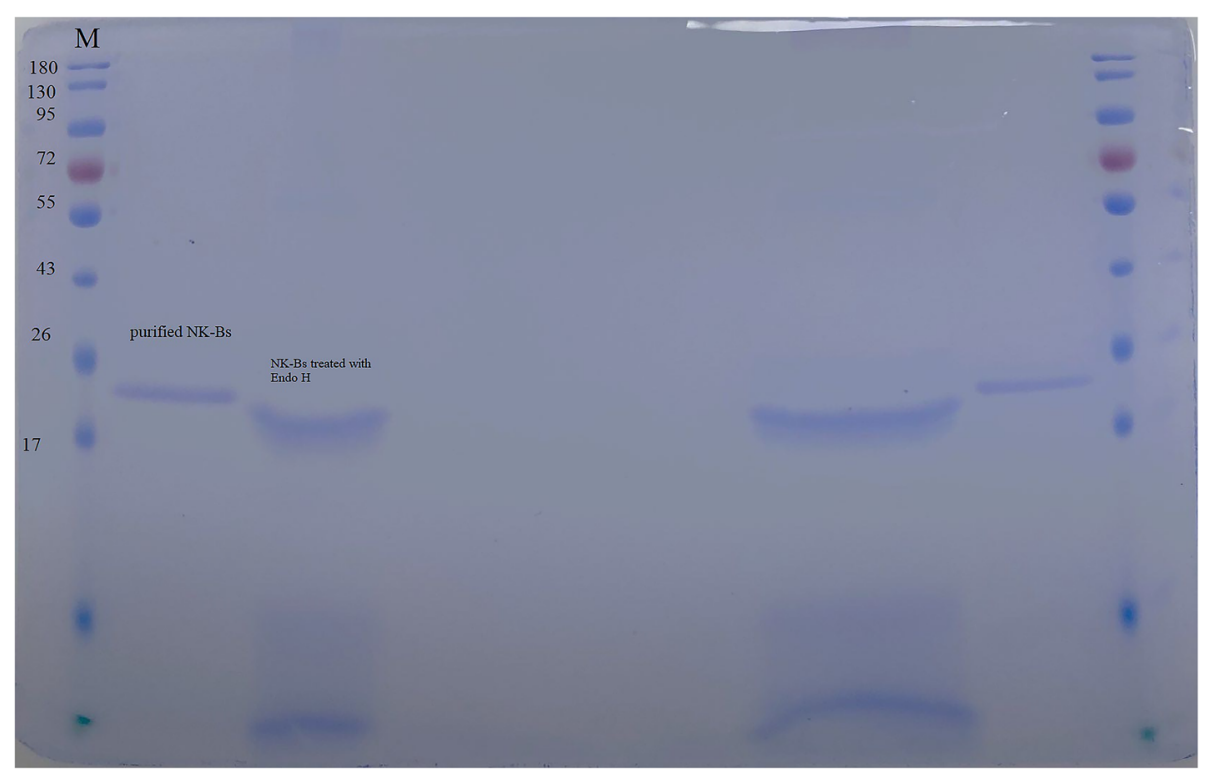

Fig. 5 Purification of NK-Bs. A SDS-PAGE of purified NK-Bs. M: protein molecular weight marker (the molecular weight of each band is indicated on the left). Lane 1: supernatant from shake-flask fermentation. Lane 2: target protein purified with $\mathrm{Ni}^{2+}$-affinity chromatography. B Glycosylation analysis of NK-Bs. Lane 1: purified NK-Bs. Lane 2: NK-Bs treated with Endo H 

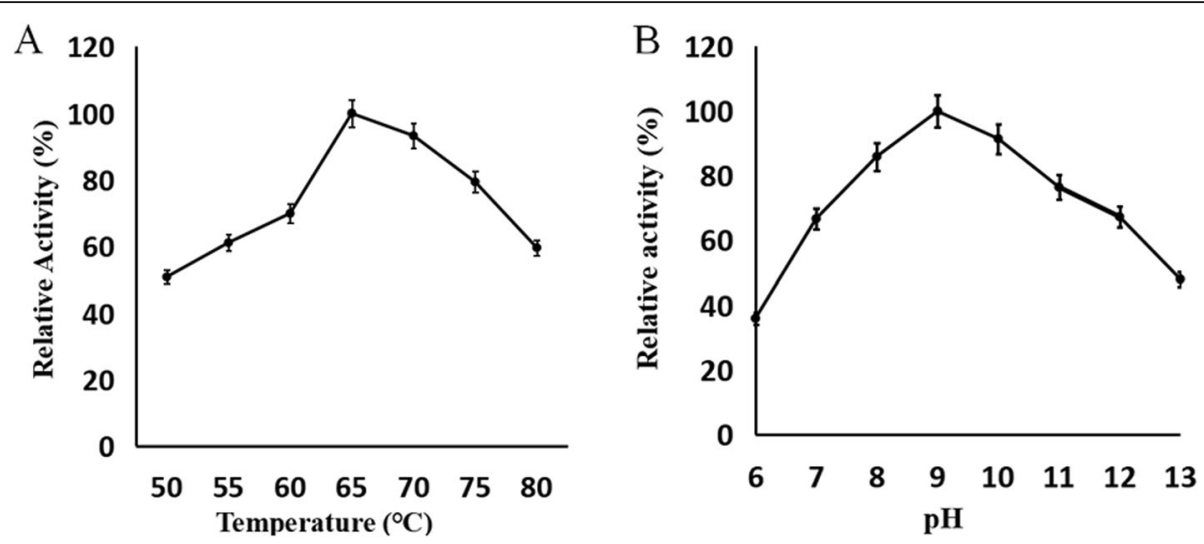

Fig. 6 The optimal temperature and pH for NK-Bs. A The optimal temperature for NK-Bs. The enzyme activity at $65^{\circ} \mathrm{C}$ was set to $100 \%$. The absolute enzyme activity, corresponding to $100 \%$ activity, was $465 \mathrm{U} / \mathrm{mL}$. B The optimal pH for NK-Bs. The enzyme activity at pH 9.0 was set to 100\%. The absolute enzyme activity, corresponding to $100 \%$ activity, was $371.7 \mathrm{U} / \mathrm{mL}$

The effects of chemical reagents and metal ions on the activity of NK-Bs were investigated. Because there is no cysteine in NK-Bs, $\beta$-mercaptoethanol had no obvious effect on the enzymatic activity (Table 1). Similarly, ethylenediaminetetraacetic acid (EDTA) had no obvious effect on the enzyme activity of NK-Bs (Table 1), indicating that NK-Bs is not a metalloprotease. However, PMSF dramatically inhibited enzyme activity (Table 1), which is consistent with a previous report that NK-Bs is a serine protease. Heavy metal ions, such as $\mathrm{Fe}^{3+}$ and $\mathrm{Cu}^{2+}$, significantly inhibited the activity of NK-Bs at both 1 and $5 \mathrm{mM}$. Similarly, $\mathrm{Zn}^{2+}, \mathrm{Fe}^{2+}, \mathrm{Ni}^{2+}$, and $\mathrm{Ba}^{2+}$ inhibited the enzymatic activity at $5 \mathrm{mM}$. In contrast, $\mathrm{Mg}^{2+}, \mathrm{Mn}^{2+}$, and $\mathrm{Ca}^{2+}$ had no obvious effects on the activity of the recombinant protein at either concentration (Table 2).

\section{The thrombolytic/fibrinolytic effect of NK-Bs in vitro}

The fibrinolytic activity of NK-Bs was tested using fibrin plates. A clear halo appeared around NK-Bs and commercial lumbrokinase, which was applied as a positive control (Fig. 8). These results demonstrated that the recombinant NK-Bs had high fibrinolytic activity.

\section{The thrombolytic/fibrinolytic effect of NK-Bs in vivo}

Straight-chained, sulfur-containing polysaccharide Kcarrageenan was used to construct a rat model of microvascular thrombosis. The dosage of $\mathrm{k}$-carrageenan used for injection was $2.0 \mathrm{mg} / \mathrm{mL}$ and the frequency of tail infarction was $85 \%$. After $4 \mathrm{~h}$, tail tips became black. Tail infarction was visible after $8 \mathrm{~h}$ and lengthened after $12 \mathrm{~h}$ (Fig. 9). The ears of the rats turned black $24 \mathrm{~h}$ after injection (Fig. 10).

After the thrombosis rat model was constructed, the rats were treated with different doses of nattokinase for 1 week, and FDPs and D-dimer levels in blood samples were analyzed. The plasma concentrations of FDP and $\mathrm{D}$-dimer of rats that received a high or medium dose of NK-Bs were similar to those treated with vermis kinase but were significantly higher than the negative control. In contrast, the concentrations of FDP and D-dimer of rats that received a low dose treatment were similar to
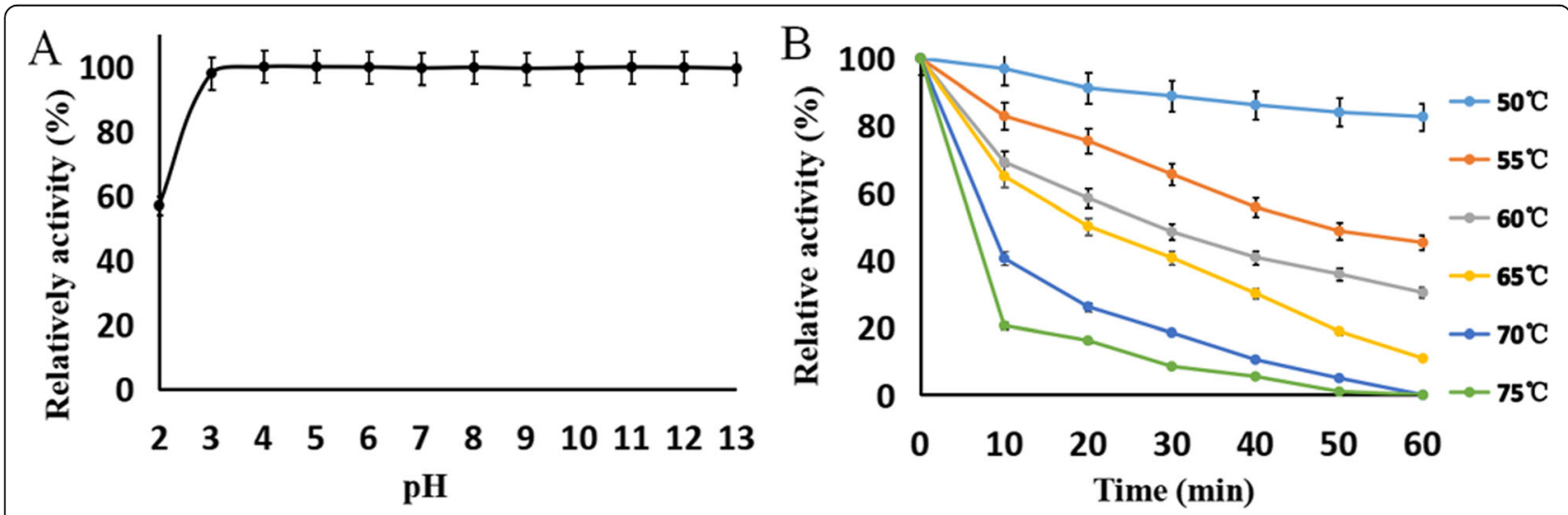

Fig. 7 Effect of $\mathrm{pH}$ and temperature on the stability of NK-Bs. $\mathbf{A} \mathrm{pH}$ stability of NK-Bs. $\mathbf{B}$ Thermostability of NK-Bs at $50-75^{\circ} \mathrm{C}$, at increments of $5^{\circ} \mathrm{C}$ 
Table 1 the effect of protease inhibitors on the activity of NKBs

\begin{tabular}{lll}
\hline inhibitor & \multicolumn{2}{l}{ residual activity (\%) } \\
\cline { 2 - 3 } & $\mathbf{1} \mathbf{~} \mathbf{M}$ & $\mathbf{2 ~} \mathbf{~ m M}$ \\
\hline$\beta$-mercaptoethanol & $97.48 \pm 3.72$ & $92.90 \pm 3.51$ \\
EDTA & $109.46 \pm 2.06$ & $105.11 \pm 4.50$ \\
PMSF & $40.17 \pm 1.84$ & $3.02 \pm 0.36$ \\
control & $100.00 \pm 1.62$ & $100.00 \pm 1.27$ \\
\hline
\end{tabular}

the negative controls (Table 3, Fig. 11). In addition, ear tissue was examined histologically. Tissue slices of normal rat ears displayed no obvious thrombosis in the lumen (Fig. 12F), whereas thrombosis was evident in the entire lumen in thrombotic rats (Fig. 12E). However, after treatment with nattokinase, the thrombosis in the lumen was significantly reduced (Fig. 12A-C). Furthermore, the reduction became more obvious as the dose of NK-Bs increased. The effect in the high dosage group was similar to that of rats treated with vermis kinase (Fig. 12D). These results indicate that the recombinant nattokinase had an obvious fibrinolytic effect, and this effect was dose dependent.

* FDP: Fibrin/fibrinogen degradation products (FDP) is the general term for fibrin degradation products and fibrinogen degradation products, including a variety of peptides of different molecular weights.

D-dimer: The fibrin monomer was first cross-linked by activated factor XIII and then hydrolyzed by plasmin. The final products were D-dimer.

\section{Discussion}

$P$. pastoris is generally regarded as safe (GRAS). In the present study, we expressed nattokinase, which has great potential as a healthcare product, using a $P$. pastoris

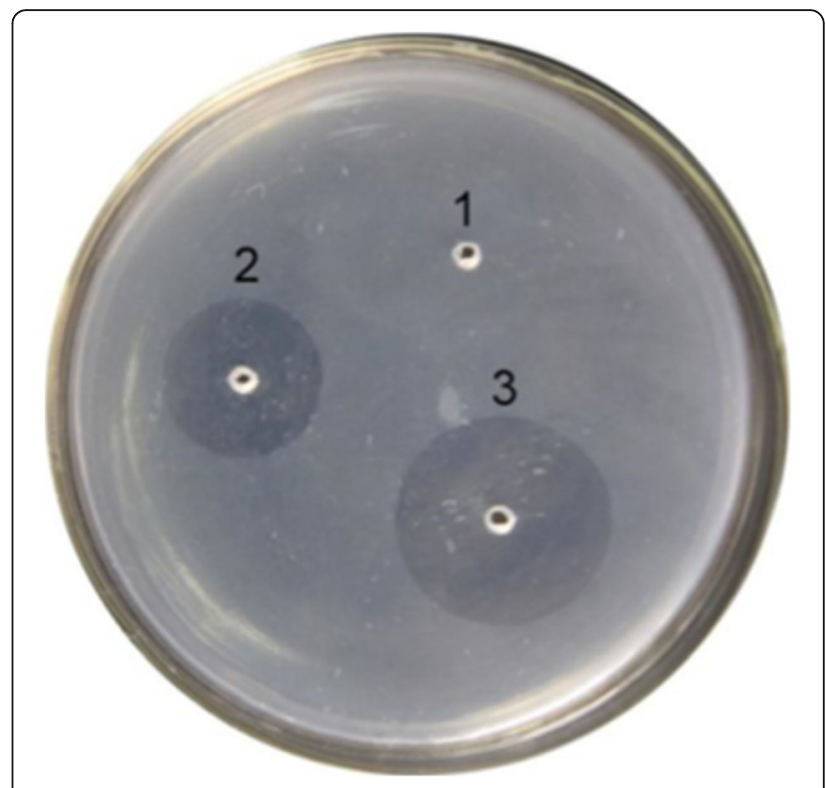

Fig. 8 Analysis of the thrombolytic activity of NK-Bs using fibrin plates. 1: negative control (10 $\mu \mathrm{L}$ physiologic saline); 2 : positive control (10 $\mu \mathrm{L}$ commercial lumbrokinase); 3:10 $\mu \mathrm{L}$ NK-Bs. scale bar, $1 \mathrm{~cm}$

secretary expression system [24-27]. In 2005, nattokinase was expressed in E. coli with oleosin fused to its $\mathrm{N}$ or C-terminus, yielding $300 \mathrm{mg} / \mathrm{L}$ of nattokinase with a recovery yield of $60 \%$ [23]. In 2013, nattokinase was also expressed in B. subtilis with a titer of $600 \mathrm{mg} / \mathrm{L}$, which was the highest expression level achieved to date [18]. Luo et al., expressed nattokinase using $P$. pastoris and obtained a target protein titer much lower than by heterologous expression in prokaryotes and original Bacillus strains [28]. There are two reasons that we significantly increase the productivity of producer strains. Firstly, the aprN gene was optimized based on

Table 2 the effect of metal ions on the activity of NK-Bs

\begin{tabular}{ccc}
\hline \multirow{2}{*}{ metal ion } & \multicolumn{2}{c}{ residual activity $(\%)$} \\
\cline { 2 - 3 } & $1 \mathrm{mM}$ & $5 \mathrm{mM}$ \\
\hline $\mathrm{MgCl}_{2}$ & $100.28 \pm 2.49$ & $84.18 \pm 3.53$ \\
$\mathrm{FeSO}_{4}$ & $102.30 \pm 2.26$ & $69.16 \pm 3.29$ \\
$\mathrm{FeCl}_{3}$ & $52.58 \pm 1.86$ & $35.41 \pm 2.95$ \\
$\mathrm{BaCl}_{2}$ & $100.28 \pm 2.41$ & $66.76 \pm 1.13$ \\
$\mathrm{NiSO}_{4}$ & $107.82 \pm 3.61$ & $76.76 \pm 0.38$ \\
$\mathrm{ZnSO}_{4}$ & $92.15 \pm 0.78$ & $56.76 \pm 1.28$ \\
$\mathrm{MnCl}_{2}$ & $100.00 \pm 1.56$ & $86.55 \pm 1.32$ \\
$\mathrm{CaCl}_{2}$ & $100.28 \pm 3.21$ & $98.56 \pm 1.53$ \\
$\mathrm{CuSO}_{4}$ & $62.27 \pm 2.03$ & $25.81 \pm 1.64$ \\
$\mathrm{Control}$ & $100.00 \pm 1.12$ & $100.00 \pm 2.15$ \\
\hline
\end{tabular}




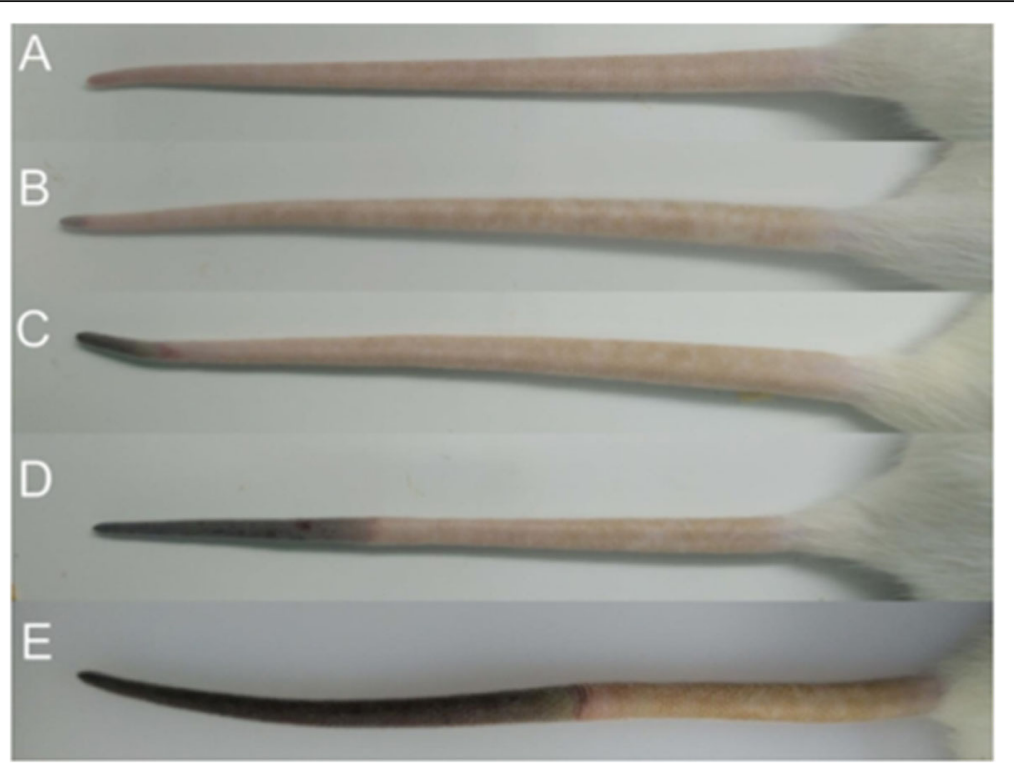

Fig. 9 Infarction of the tips of the tails of rats injected with $\mathrm{k}$-carrageenan. AControl group; B $4 \mathrm{~h}$ post-injection; C $8 \mathrm{~h}$ post-injection; D $12 \mathrm{~h}$ postinjection; E $24 \mathrm{~h}$ post-injection. Scale bar, $0.5 \mathrm{~cm}$

the codon preference of P. pastoris and then synthesized. But Luo cloned the nattokinase gene directly from B.subilit and inserted into the pPICZ $\alpha \mathrm{A}$ vector. The naturel nattokinase gene maybe not appropriate expressed in P.pastoris. Secondly, we used vector pHBM905BDM which has a $\mathrm{dl}+2 \times 201$ AOX1 and a MF4I leader sequence. This strong $\mathrm{dl}+2 \times 201$ AOX1 promoter could significantly improved the protein express level. However, Luo only used the original pPICZ $\alpha$ A vector which has only a AOX1 promoter. In comparison with these reports, the maximum expression level of nattokinase in the present study was $320 \mathrm{mg} / \mathrm{L}$ with shake-flask fermentation and $9.5 \mathrm{~g} / \mathrm{L}$ with high-density fermentation. Moreover, the recombinant nattokinase displayed remarkable thermo- and $\mathrm{pH}$-stability. Consistent with the previous report, the NK-Bs produced in the present study had over 60\% activity at $\mathrm{pH} 7.0-11.0$. Previous reports have indicated that acidic conditions cause a rapid decease in the enzyme activity of nattokinases, whereas the recombinant NK-Bs in the present study remained almost fully activity after incubation at $\mathrm{pH} 2.0-13.0$ for $1 \mathrm{~h}$. Previous studies have also indicated that nattokinases are stable at temperatures lower than $40^{\circ} \mathrm{C}$ but lose all initial activity after $10 \mathrm{~min}$ at $60^{\circ} \mathrm{C}$ or $1 \mathrm{~h}$ at $50^{\circ} \mathrm{C}$. A thermostable nattokinase purified from $B$. subtilis $\mathrm{B} 12$ was relatively stable below $50^{\circ} \mathrm{C}$, but nearly $70 \%$ of its enzyme activity was lost at $60^{\circ} \mathrm{C}$ for $40 \mathrm{~min}$. The recombinant NK-Bs in the present study retained more than 50 and $40 \%$ of its enzymatic activity after incubation for $30 \mathrm{~min}$ at $60^{\circ} \mathrm{C}$ and 65 , respectively In addition, the present study also demonstrated that the recombinant NK-Bs had obvious thrombolytic activity, demonstrating that NK-Bs prepared with $P$. pastoris could be applied to health promotion. Altogether, the present study provides an ideal platform for the large-scale preparation of nattokinase at low cost.

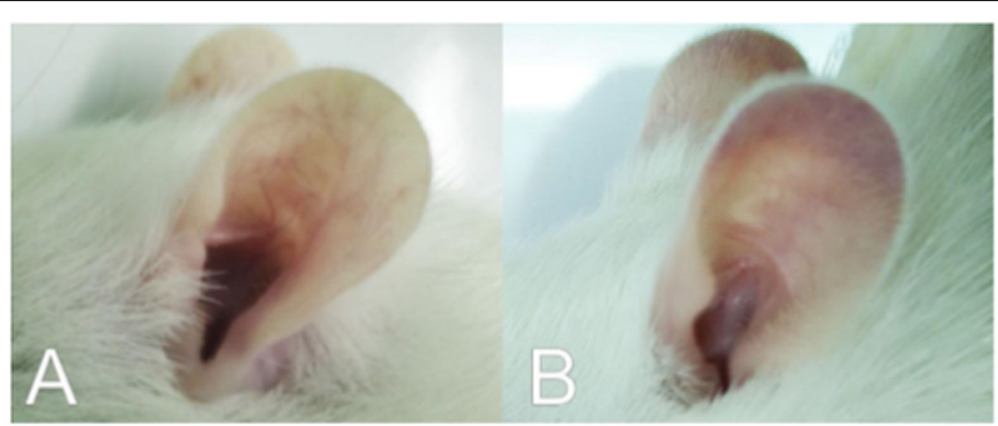

Fig. 10 Ears of rats (A) before and (B) $24 \mathrm{~h}$ after injection with $\mathrm{K}$-carrageenan 
Table 3 The physiological parameters of rats after the nattokinase treatment

\begin{tabular}{llll}
\hline groups of rats & dosage of enzymes (IU/kg) & FDP $(\mathbf{p g} / \mathbf{m L})$ & D-dimer $(\mathbf{n g} / \mathbf{m L})$ \\
\hline Positive control (vermis kinase) & 10,000 & $5.12 \pm 0.31$ & $15.02 \pm 2.36$ \\
High dosage & 50,000 & $6.17 \pm 0.32$ & $17.85 \pm 2.10$ \\
Medium dosage & 10,000 & $4.36 \pm 0.21$ & $13.59 \pm 1.29$ \\
Low dosage & 2000 & $2.04 \pm 0.06$ & $8.42 \pm 1.88$ \\
Negative control (physiologic saline) & 0 & $1.84 \pm 0.27$ & $6.00 \pm 0.87$ \\
\hline
\end{tabular}

\section{Conclusions}

In this study, we achieved high levels expression of nattokinase from $B$. subtilis natto (NK-Bs) using a Pichia pastoris heterologous expression system and assess its fibrinolytic activity in vivo. Multicopy expression strains bearing 1-7 copies of the apr $\mathrm{N}$ gene were constructed. The expression level of the target protein reached a maximum at five copies of the target gene. However, multicopy expression strains were not stable in shakeflask or high-density fermentation, causing significant differences in the yield of the target protein among batches. Therefore, $P$. pastoris bearing a single copy of $a p r \mathrm{~N}$ was used in shake-flask and high-density fermentation. Target protein yield was $320 \mathrm{mg} / \mathrm{L}$ in shake-flask fermentation and approximately $9.5 \mathrm{~g} / \mathrm{L}$ in high-density fermentation. The recombinant nattokinase showed high thermo- and $\mathrm{pH}$-stability. The present study also demonstrated that recombinant NK-Bs had obvious thrombolytic activity.

\section{Materials and methods}

All methods were carried out in accordance with relevant guidelines and regulations.

All experimental protocols were approved by Zhongnan Hospital of Wuhan University.

\section{Strains, plasmids, and media}

E. coli XL10-Gold and P. pastoris GS115 were purchased from Invitrogen (USA). The vector pUC57 was purchased from GenScript (USA), and pHMB905BDM $(\mathrm{d} 1+2 \times 201 \quad A O X 1$ promoter [29], MF4I signal sequence, $A m p^{r}$ ) was constructed and stored in our lab. Luria-Bertani (LB) medium was prepared as described in the Manual of Molecular Cloning. Buffered glycerolcomplex (BMGY) medium, buffered methanol-complex (BMMY) medium, and minimal dextrose (MD) medium were prepared as described in the instruction manual of the Invitrogen Pichia expression kit (USA) [29, 30]. BMMY medium supplemented with casein was prepared by dissolving $1 \%$ casein in phosphate buffer ( $\mathrm{pH} 6.0$ ), followed by the addition of BMMY ingredients and sterilization at $121^{\circ} \mathrm{C}$ for $20 \mathrm{~min}$. Lumbrokinase and fibrinogen were purchased from Sigma (USA).

\section{Design and synthesis of the truncated NK-Bs-encoding open reading frame}

A truncated nattokinase-encoding gene from $B$. subtilis (NK-Bs) was used for heterologous expression. The DNA sequence of NK-Bs, excluding the first 52-bp signal sequence, was modified to match the codon usage bias of $P$. pastoris (S1). This edited open reading frame (ORF) was synthesized by Genecreate (China) and cloned into pUC57 for DNA sequencing.

\section{Construction of recombinant vectors for the expression of NK-Bs}

The aprN gene of B. subtilis natto (Genbank accession number AEV91244.1) without the signal peptide coding sequence was optimized based on the codon preference of $P$. pastoris and synthesized. The DNA fragment was
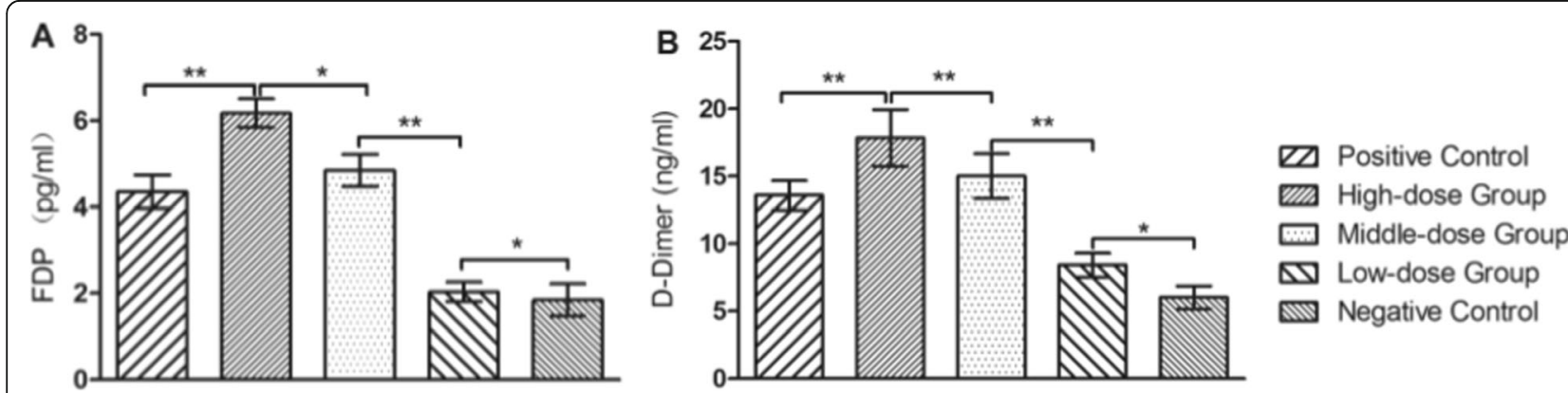

Fig. 11 Changes in plasma concentrations of FDPs and D-dimer after nattokinase treatment. According to the concentration of the standard, we calculated the FDP and D-dimer concentrations using the OD value of the samples. ${ }^{*}$ and ${ }^{* *}$ indicate statistically significant differences at $P \leq 0.05$ and $P \leq 0.01$, respectively. A Changes in plasma concentrations of FDPs of rats that treated by different levels of NK-Bs. BChanges in plasma concentrations of D-dimer of rats that treated by different levels of NK-Bs 


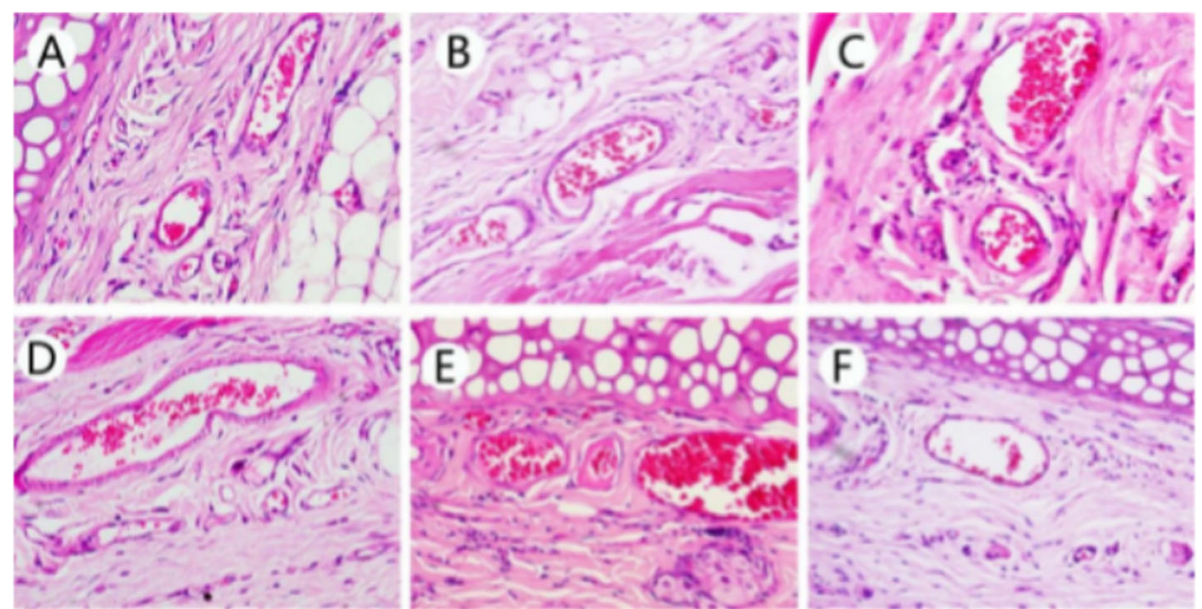

Fig. 12 Tissue biopsies of the ears of thrombotic rats treated with different doses of NK-Bs. A High dose of NK-Bs; B medium dose of NK-Bs; C low dose of NK-Bs; D positive control (treated with vermis kinase); E negative control (treated with physiologic saline); Frats not given K-

carrageenan treatment. Scale bar, $100 \mu \mathrm{m}$

cloned into the expression vector pHBM905BDM to form an ORF encoding an NK-Bs protein fused with an $\mathrm{N}$-terminal MF-4I leader sequence for secretory expression and a C-terminal $6 \times$ His-tag for affinity purification. It was amplified using the primers Natt-1 and Natt-2 (Table S1) and subsequently treated with T4 DNA polymerase in the presence of $1 \mathrm{mM}$ deoxythymidine triphosphate (dTTP) for $20 \mathrm{~min}$ at $12^{\circ} \mathrm{C}$ to form overhangs compatible with the sticky ends of pHBM905BDM digested with CpoI and NotI $[29,30]$. These two fragments were ligated with $\mathrm{T} 4$ ligase (TaKaRa, China), followed by transformation into E. coli XL10-Gold and screening on LB plates supplemented with $100 \mu \mathrm{g} / \mathrm{mL}$ ampicillin. Biobrick assembly was used for the construction of multicopy nattokinase expression vectors.

\section{Screening of recombinant yeast strains expressing NK-Bs} The recombinant plasmids were linearized using SalI and transformed into P. pastoris GS115 by electroporation $(7000 \mathrm{~V} / \mathrm{cm}, 25 \mu \mathrm{F}, 400 \times$; Life Technologies CellPorator, USA). Transformants were selected on MD plates without histidine, followed by identification on BMMY plates supplemented with $1 \%$ casein $[29,30]$.

\section{Expression of recombinant NK-Bs using shake-flask fermentation}

Recombinants bearing different copies of the target gene were inoculated into $50 \mathrm{~mL}$ BMGY medium and incubated at $28^{\circ} \mathrm{C}$ for 2 days. The cells in each culture were collected by centrifugation at $4000 \times \mathrm{g}$ for $5 \mathrm{~min}$ and individually inoculated into $30 \mathrm{~mL}$ BMMY medium. Then, $1 \%(\mathrm{v} / \mathrm{v})$ methanol was added every $24 \mathrm{~h}$ to induce the expression of the foreign protein. Cell cultures were centrifuged at $10,000 \times \mathrm{g}$ for $5 \mathrm{~min}$ at $4{ }^{\circ} \mathrm{C}$ after induction for 5 days, and the supernatants were collected.

\section{Sodium dodecyl sulfate-polyacrylamide gel} electrophoresis and protein concentration measurements Samples were separated using sodium dodecyl sulfatepolyacrylamide gel electrophoresis (SDS-PAGE) on a $12 \%(\mathrm{w} / \mathrm{v})$ polyacrylamide gel, followed by staining with Coomassie Brilliant Blue G-250. Protein concentrations were determined using the Bradford method with a BCA protein kit (Pierce, USA). A standard curve was created using bovine serum albumin with concentrations ranging from 0.1 to $0.6 \mathrm{mg} / \mathrm{mL}[29,30]$.

\section{Purification of the target protein}

After induction with methanol for $120 \mathrm{~h}$, the supernatant of the cell culture was collected and purified using $\mathrm{Ni}$ NTA affinity chromatography. Approximately $20 \mathrm{~mL}$ of the supernatant was applied to $1 \mathrm{~mL}$ Ni-NTA beads. The column was washed twice with two column volumes of wash buffer $(50 \mathrm{mM}$ Tris- $\mathrm{HCl} ; 200 \mathrm{mM} \mathrm{NaCl}$; $50 \mathrm{mM} \mathrm{NaH} \mathrm{PO}_{4} ; 40 \mathrm{mM}$ imidazole, $\mathrm{pH}$ 8.0). One column volume of elution buffer $(50 \mathrm{mM}$ Tris- $\mathrm{HCl} ; 200$ $\mathrm{mM} \mathrm{NaCl} ; 50 \mathrm{mM} \mathrm{NaH} \mathrm{PO}_{4} ; 200 \mathrm{mM}$ imidazole, $\mathrm{pH}$ 8.0) was used to recover the target protein. The sample was then collected and dialyzed using a Millipore 10$\mathrm{kDa}$ cut-off membrane at $4{ }^{\circ} \mathrm{C}$ to remove ions and salts, followed by resuspension in storage buffer $(50 \mathrm{mM}$ Tris$\mathrm{HCl}, \mathrm{pH} 7.5)[29,30]$.

\section{Analysis of the serine proteinase activity of NK-Bs}

Enzyme activity was measured using casein as the substrate. Briefly, $1 \mathrm{~mL}$ of diluted enzyme sample was mixed with an equal volume of $2 \%(\mathrm{w} / \mathrm{v})$ casein in $20 \mathrm{mM}$ 
phosphate buffer (pH 9.0), followed by incubation at $65^{\circ} \mathrm{C}$ for $10 \mathrm{~min}$. The reaction was terminated using 2 $\mathrm{mL}$ of $10 \%(\mathrm{w} / \mathrm{v})$ trichloroacetic acid. The mixture was centrifuged at $14,000 \times \mathrm{g}$ for $10 \mathrm{~min}$ and the optical density at $280 \mathrm{~nm}\left(\mathrm{OD}_{280}\right)$ of the supernatant was measured to determine the amount of tyrosine released during the reaction. One unit of enzymatic activity was defined as the amount of enzyme needed to catalyze the release of $1 \mu \mathrm{g}$ tyrosine per min at $65^{\circ} \mathrm{C}$ and $\mathrm{pH} 9.0$. All experiments were performed in triplicate [29].

\section{Analysis of the characteristics of NK-Bs}

To measure the optimal $\mathrm{pH}$ value for the recombinant enzyme, the $\mathrm{pH}$ of the enzyme solution was adjusted using the following buffers: sodium lactate $(50 \mathrm{mM}, \mathrm{pH}$ 2.0-3.5); sodium acetate $(50 \mathrm{mM}, \mathrm{pH} 3.5-6.0)$; phosphate buffer (50 mM, pH 6.0-7.0); Tris- $\mathrm{HCl}(50 \mathrm{mM}$, $\mathrm{pH} 7.0-9.0$ ), or $\mathrm{Na}_{2} \mathrm{~B}_{4} \mathrm{O}_{7} / \mathrm{NaOH}(50 \mathrm{mM}$, pH 9.0-12.0). The enzyme activity was then measured at $55^{\circ} \mathrm{C}$.

To determine the optimal temperature for the recombinant enzyme, the enzyme was diluted with $\mathrm{Na}_{2} \mathrm{~B}_{4} \mathrm{O}_{7} /$ $\mathrm{NaOH}$ buffer ( $50 \mathrm{mM}, \mathrm{pH} 10.5)$ to the appropriate concentration, and the reaction was carried out at a range of temperatures $\left(50-80{ }^{\circ} \mathrm{C}\right.$, at $5{ }^{\circ} \mathrm{C}$ increments).

To investigate the thermostability of NK-Bs, the purified NK-Bs was divided into six samples and incubated at $50^{\circ} \mathrm{C}, 55^{\circ} \mathrm{C}, 60^{\circ} \mathrm{C}, 65^{\circ} \mathrm{C}, 70^{\circ} \mathrm{C}$, or $75^{\circ} \mathrm{C}$. Exactly $1 \mathrm{~mL}$ of each sample was collected every $10 \mathrm{~min}$, and the remaining enzyme activity of all samples was measured at $\mathrm{pH} 9.0$ and $65^{\circ} \mathrm{C}$.

To investigate the $\mathrm{pH}$ stability of NK-Bs, purified NKBs was incubated at $\mathrm{pH} 2-13$ for $60 \mathrm{~min}$, and the activity of the remaining enzyme was measured at $\mathrm{pH} 9.0$ and $65^{\circ} \mathrm{C}$. Each experiment was performed in triplicate.

\section{Expression of recombinant NK-Bs using high-density fermentation}

Fed-batch fermentation was performed according to the Invitrogen Pichia Fermentation Process Guidelines. The recombinant $P$. pastoris strain was inoculated into 200 $\mathrm{mL}$ YPD and cultivated at $28^{\circ} \mathrm{C}$ for $24 \mathrm{~h}$. The cell culture was then transferred to $2 \mathrm{~L}$ BSM medium in a $5-\mathrm{L}$ fermenter (BaoXing, China). During the early stages of fermentation, the culture was maintained at $28^{\circ} \mathrm{C}, \mathrm{pH}$ 5.8 , and $30 \%$ dissolved oxygen (DO). After approximately $18-24 \mathrm{~h}$, glycerol was exhausted and DO was rapidly increased to $100 \%$. To continue cell growth, 50\% (v/v) glycerol supplemented with PTM trace salts (12 $\mathrm{mL} / \mathrm{L}$ ) was added at $12 \mathrm{~mL} / \mathrm{h} / \mathrm{L}$, and $\mathrm{DO}$ was maintained above $20 \%$. When the $\mathrm{OD}_{600}$ reached approximately 300 , methanol containing PTM trace salts $(12 \mathrm{~mL} / \mathrm{L})$ was fed at a speed of $3 \mathrm{~mL} / \mathrm{h} / \mathrm{L}$ to induce the expression of the target gene. The fermentation conditions were adjusted to $25^{\circ} \mathrm{C}$ and $\mathrm{pH} 5.0$, and DO was maintained at $20-30 \%$.
After $2 \mathrm{~h}$, the feeding speed of methanol was increased by a ratio of $20 \%$ per hour until it reached $7 \mathrm{~mL} / \mathrm{h} / \mathrm{L}$. These conditions were maintained until the end of fermentation $[29,30]$.

\section{Analysis of the fibrinolytic activity of NK-Bs in vitro}

Fibrinolytic activity was measured using the standard fibrin plate method with modifications [31]. In a petri dish, $7.3 \mathrm{~mL}$ agarose $(0.5 \% \mathrm{w} / \mathrm{v})$ and $200 \mu \mathrm{L}$ bovine thrombin $(1 \mathrm{mg} / \mathrm{mL})$ were gently mixed, followed by the addition of $2.5 \mathrm{~mL}$ bovine fibrinogen ( $1 \% \mathrm{w} / \mathrm{v})$ to induce a solid fibrin formation. The fibrin plate was incubated at $37^{\circ} \mathrm{C}$ for $18 \mathrm{~h}$ after $10 \mu \mathrm{L}$ of the enzyme sample was injected into the bottom of the fibrin agar. The diameters of the clearing zones were used as indicators of the fibrinolytic activity of the enzyme.

\section{Analysis of the fibrinolytic effect of NK-Bs in vivo}

To test the thrombolytic activity of recombinant NK-Bs in vivo, a rat model of microvascular thrombosis was established [32]. Female Sprague-Dawley rats weighing approximately $180-220 \mathrm{~g}$ were used. Thrombosis was induced by hypodermic injection of $\mathrm{k}$-carrageenan after the rats were fasted for $8 \mathrm{~h}$. Thrombosis was evaluated by the length of tail infarction. The length of the infarcted region at the tip of the tail was measured 8, 12, and $24 \mathrm{~h}$ after injection. After the thrombosis model was established, the rats were split into six groups. Different dosages of the recombinant NK-Bs $(50,000 \mathrm{IU} / \mathrm{kg}$ for high dose, 10,000 IU/kg for medium dose, and $2000 \mathrm{IU} /$ $\mathrm{kg}$ for low dose) were fed to the rats every $12 \mathrm{~h}$ for $48 \mathrm{~h}$. Vermis kinase, a known thrombolytic agent, was used as a positive control $(10,000 \mathrm{IU} / \mathrm{kg})$, and physiologic saline was used as the negative control. Each group included five duplicates.

Twelve hours after intragastric administration, the rats were anaesthetized by intraperitoneal injection with 50\% ethyl carbamate at a dose of $5 \mathrm{~mL} / \mathrm{kg}$. Approximately $1.8 \mathrm{~mL}$ of blood from the postcaval vein was drawn into anticoagulant tubes containing $0.2 \mathrm{~mL}$ sodium citrate $(0.109 \mathrm{~mol} / \mathrm{L})$. The blood in the tubes was centrifuged at $4000 \times \mathrm{g}$ for $15 \mathrm{~min}$, and $250 \mu \mathrm{L}$ of the top layer of plasma was collected. Fibrin/fibrinogen degradation products (FDPs) and D-dimer levels were measured using the double antibody sandwich method (ABC-ELISA) according to the manufacturer's protocol (Elabscience Biotechnology, China). Probabilities of less than 5\% $(P<0.05)$ were considered statistically significant. All values are expressed as mean \pm standard error of mean (S.E.M.) to show variation in groups.

\section{Histological examination}

Histological examination was carried out as previously described $[8,9,33]$. Twelve hours after the nattokinase 
treatment was completed, rats were euthanized by spinal dislocation, and ear tissue was soaked in a formaldehyde solution before preparation of pathological sections. The tissue samples were embedded with paraffin and stained with hematoxylin and eosin for observation under a Upright optical microscope (Nikon Eclipse E100, Nikon DS-U3, 400).

\section{Abbreviations}

NK-Bs: nattokinase from B. subtilis natto; MD: Minimal dextrose medium; BMMY: Buffered methanol-complex medium; BMGY: Buffered glycerolcomplex medium; SDS-PAGE: sodium dodecyl sulfate-polyacrylamide gel electrophoresis; EDTA: ethylenediaminetetraacetic acid;

PMSF: phenylmethylsulfonyl fluoride; FDP: Fibrin/fibrinogen degradation products

\section{Supplementary Information}

The online version contains supplementary material available at https://doi. org/10.1186/s12896-021-00708-4.

Additional file 1: Fig. S1. Analyzing the relation between expression levels of NK-Bs and the copy number of aprN gene with plate assay. Table S1. Primers for the amplification of ORF encoding NK-Bs. Table S2. The ratio of the opaque halo diameter to the colony diameter.

\section{Acknowledgments}

Not Applicable.

\section{Authors' contributions}

YGB, MLX and WYP conceived and designed the experiments. YGB, SM and SW performed the experiments. ZC, YGB and WYP analyzed the data. YGB wrote the manuscript. All authors reviewed and approved the manuscript.

\section{Funding}

The study received the funding from National key research and development program of China (2017YFB0308401) and a major technological innovation project in Hubei province (2017ACA174), State Key Laboratory of Biocatalysis and Enzyme Engineering, School of Life Sciences (SKLBEE2018003, SKLBEE2018004), Joint Open Fund of National Biopesticide Engineering Research Centre and Scientific Observation and Experimental Station of Utilization of microbial resources (Central China), Ministry of Agriculture and Rural Affairs (Grant No. JF-NBCOES-1807), National Key R D Program of China (2017YFD0200900) Subject 2 (2017YFD0200902), Natural Science Foundation of China $(31300074,21606076)$, Natural Science Foundation of Hubei Province (2014CFB541), Specialized Research Fund for the Doctoral Program of Higher Education (20124208120004).

\section{Availability of data and materials}

The datasets supporting the conclusions of this article are included with in the article and its additional files. All strain materials were obtained from Hubei University, Wuhan, China.

\section{Declarations}

Ethics approval and consent to participate

All animal experiments were conducted in accordance with international ethical guidelines and the National Institutes of Health Guide concerning the Care and Use of Laboratory Animals. The experimental protocol was approved by Zhongnan Hospital of Wuhan University.

\section{Consent for publication}

Not Applicable.

\section{Competing interests}

The authors declare that they have no competing interests.

\section{Author details}

${ }^{1}$ State Key Laboratory of Biocatalysis and Enzyme, Engineering Hubei Collaborative Innovation Center for Green Transformation of Bio-Resources, Hubei Key Laboratory of Industrial Biotechnology, Biology Faculty of Hubei University, Hubei University, Wuhan, Hubei Province 430062, People's Republic of China. ${ }^{2}$ School of Life Sciences, Yunnan Normal University, Kunming, Yunnan, People's Republic of China.

Received: 19 September 2020 Accepted: 14 July 2021

Published online: 09 August 2021

\section{References}

1. Sumi $H$, Hamada $H$, Tsushima $H$, Mihara $H$, Muraki $H$. A novel fibrinolytic enzyme (nattokinase) in the vegetable cheese Natto; a typical and popular soybean food in the Japanese diet. Cell Mol Life Sci 1987; 43(10):1110-1, 1111, DOI: https://doi.org/10.1007/BF01956052.

2. Nakamura T, Yamagata Y, Ichishima E. Nucleotide sequence of the Subtilisin NAT gene, aprN, of Bacillus subtilis (natto). Biosci Biotech Bioch. 1992;56(11): 1869-71. https://doi.org/10.1271/bbb.56.1869.

3. Zheng ZL, Zuo ZY, Liu ZG, Tsai KC, Liu AF, Zou GL. Construction of a 3D model of nattokinase, a novel fibrinolytic enzyme from Bacillus natto. A novel nucleophilic catalytic mechanism for nattokinase. J Mol Graph Model. 2005;23(4):373-80. https://doi.org/10.1016/j.jmgm.2004.10.002

4. Yanagisawa Y, Chatake T, Chiba-Kamoshida K, Naito S, Ohsugi T, Sumi H, et al. Purification, crystallization and preliminary $X$-ray diffraction experiment of nattokinase from Bacillus subtilis natto. Acta Crystallogr F. 2010;66(12): 1670-3. https://doi.org/10.1107/S1744309110043137.

5. Yanagisawa $Y$, Chatake T, Naito S, Ohsugi T, Morimoto $Y$. X-ray structure determination and deuteration of nattokinase. J Synchrotron Radiat. 2013; 20(6):875-9. https://doi.org/10.1107/S0909049513020700.

6. Peng $Y$, Yang $X$, Zhang Y. Microbial fibrinolytic enzymes: an overview of source, production, properties, and thrombolytic activity in vivo. Appl Microbiol Biot. 2005;69(2):126-32. https://doi.org/10.1007/s00253-005-0159-7.

7. Kamiya S, Hagimori M, Ogasawara M, Arakawa M. In vivo evaluation method of the effect of nattokinase on carrageenan-induced tail thrombosis in a rat model. Acta Haematol-Basel. 2010;124(4):218-24. https://doi.org/10.1159/ 000321518.

8. Xu J, Du M, Yang X, Chen Q, Chen H, Lin DH. Thrombolytic effects in vivo of Nattokinase in a carrageenan-induced rat model of thrombosis. Acta Haematol-Basel. 2014;132(2):247-53. https://doi.org/10.1159/000360360.

9. Urano T, Ihara H, Umemura K, Suzuki Y, Oike M, Akita S, et al. The Profibrinolytic enzyme Subtilisin NAT purified from Bacillus subtilis cleaves and inactivates plasminogen activator inhibitor type 1. J Biol Chem. 2001; 276(27):24690-6. https://doi.org/10.1074/jbc.M101751200.

10. Hsia CH, Shen MC, Lin JS, Wen YK, Yang NC. Nattokinase decreases plasma levels of fibrinogen, factor VII, and factor VIII in human subjects. Nutr Res. 2009;29(3):190-6. https://doi.org/10.1016/j.nutres.2009.01.009.

11. Tai MW, Sweet BV. Nattokinase for prevention of thrombosis. Am J HealthSyst Ph. 2006;63(12):1121-3. https://doi.org/10.2146/ajhp050509.

12. Dabbagh F, Negahdaripour M, Berenjian A, Behfar A, Mohammadi F, Zamani M, et al. Nattokinase: production and application. Appl Microbiol Biot. 2014; 98(22):9199-206. https://doi.org/10.1007/s00253-014-6135-3.

13. Chen PT, Chao YP. Enhanced production of recombinant nattokinase in Bacillus subtilis by the elimination of limiting factors. Biotechnol Lett. 2006; 28(19):1595-600. https://doi.org/10.1007/s10529-006-9126-3.

14. Deepak V, Kalishwaralal K, Ramkumarpandian S, Babu SV, Senthilkumar SR, Sangiliyandi G. Optimization of media composition for Nattokinase production by Bacillus subtilis using response surface methodology. Bioresource Technol. 2008;99(17):8170-4. https://doi.org/10.1016/j.biortech.2 008.03.018.

15. Ku TW, Tsai RL, Pan TM. A simple and cost-saving approach to optimize the production of subtilisin NAT by submerged cultivation of Bacillus subtilis natto. J Agr Food Chem. 2009;57(1):292-6. https://doi.org/10.1021/jf8024198.

16. Kwon EY, Kim KM, Lee IY, Kim BS. Production of nattokinase by high cell density fed-batch culture of Bacillus subtilis. Bioproc Biosyst Eng. 2011;34(7): 789-93. https://doi.org/10.1007/s00449-011-0527-x

17. Unrean P, Nguyen NHA. Metabolic pathway analysis and kinetic studies for production of nattokinase in Bacillus subtilis. Bioproc Biosyst Eng. 2013;36(1): 45-56. https://doi.org/10.1007/s00449-012-0760-y.

18. Nguyen TT, Quyen TD, Le HT. Cloning and enhancing production of a detergent- and organic-solvent-resistant nattokinase from Bacillus subtilis 
VTCC-DVN-12-01 by using an eight-protease-gene-deficient Bacillus subtilis WB800. Microb Cell Factories. 2013;12(1):79. https://doi.org/10.1186/1475-2 859-12-79.

19. Liang $X$, Zhang L, Zhong J, Huan L. Secretory expression of a heterologous nattokinase in Lactococcus lactis. Appl Microbiol Biot. 2007;75(1):95-101. https://doi.org/10.1007/s00253-006-0809-4.

20. Liang $X$, Jia S, Sun Y, Chen M, Chen X, Zhong J, et al. Secretory expression of Nattokinase from Bacillus subtilis YF38 in Escherichia coli. Mol Biotechnol. 2007;37(3):187-94. https://doi.org/10.1007/s1 2033-007-0060-y.

21. Wei X, Zhou Y, Chen J, Cai D, Wang D, Qi G, et al. Efficient expression of nattokinase in Bacillus licheniformis: host strain construction and signal peptide optimization. J Ind Microbiol Biot. 2015;42(2):287-95. https://doi. org/10.1007/s10295-014-1559-4.

22. Li X, Wang X, Xiong S, Zhang J, Cai L, Yang Y. Expression and purification of recombinant nattokinase in Spodoptera frugiperda cells. Biotechnol Lett. 2007;29(10):1459-64. https://doi.org/10.1007/s10529-007-9426-2.

23. Chiang CJ, Chen, Chao YP, Tzen JTC. Efficient system of artificial oil bodies for functional expression and purification of recombinant nattokinase in Escherichia coli. J Agr Food Chem. 2005;53(12):4799-804. https://doi.org/10.1 021/j050264a.

24. Cai D, Wei X, Qiu Y, Chen Y, Chen J, Wen Z, et al. High-level expression of nattokinase in Bacillus licheniformis by manipulating signal peptide and signal peptidase. J Appl Microbiol. 2016;121(3):704-12. https://doi.org/1 $0.1111 / \mathrm{jam} .13175$

25. Hsieh CW, Lu WC, Hsieh WC, Huang YP, Lai CH, Ko WC. Improvement of the stability of nattokinase using $\gamma$-polyglutamic acid as a coating material for microencapsulation. Food Sci Biotechnol. 2009;42(1):144-9.

26. Wang C, Du M, Zheng D, Kong F, Zu G, Feng Y. Purification and characterization of nattokinase from Bacillus subtilis natto B-12. J Agr Food Chem. 2009;57(20):9722-9.

27. Fujita M, Nomura K, Hong K, Ito Y, Asada A, Nishimuro S. Purification and characterization of a strong fibrinolytic enzyme (nattokinase) in the vegetable cheese natto, a popular soybean fermented food in Japan. Biochem Bioph res Co. 1993;197(3):1340-7. https://doi.org/10.1006/bbrc.1 993.2624.

28. Luo LX, Huang ZL, Pan L, Yang RD, Liang SZ. Expression of nattokinase gene in yeast Pichia pastoris. J South China Univ Technol. 2003;2:1-4.

29. Shu M, Shen W, Yang S, Wang X, Wang F, Wang Y, et al. High-level expression and characterization of a novel serine protease in Pichia pastoris by multi-copy integration. Enzyme Microb Tech. 2016;92:56-66. https://doi. org/10.1016/j.enzmictec.2016.06.007.

30. Yang H, Zhai C, Yu X, Li Z, Tang W, Liu Y, et al. High-level expression of proteinase $\mathrm{K}$ from Tritirachium album limber in Pichia pastoris using multicopy expression strains. Protein Expres Purif. 2016;122:38-44. https://doi. org/10.1016/.jpep.2016.02.006.

31. Astrup T, Müllertz S. The fibrin plate method for estimating fibrinolytic activity. Arch Biochem Biophys. 1952;40(2):346-51. https://doi.org/10.1016/ 0003-9861(52)90121-5.

32. Bekemeier $\mathrm{H}$, Giessler RHJ. Carrageenin-induced thrombosis in rats and mice: a model for testing antithrombotic substances? Inflamm Res. 1985; 16(5):446-51.

33. Yatagai C, Maruyama M, Kawahara T, Sumi H. Nattokinase-promoted tissue plasminogen activator release from human cells. Pathophysiol Haemo T. 2008:36(5):227-32.

\section{Publisher's Note}

Springer Nature remains neutral with regard to jurisdictional claims in published maps and institutional affiliations.

Ready to submit your research? Choose BMC and benefit from:

- fast, convenient online submission

- thorough peer review by experienced researchers in your field

- rapid publication on acceptance

- support for research data, including large and complex data types

- gold Open Access which fosters wider collaboration and increased citations

- maximum visibility for your research: over $100 \mathrm{M}$ website views per year

At BMC, research is always in progress.

Learn more biomedcentral.com/submissions 